Os OlHOS DA MONTANHA ENCONTRAM O SOL

straçöes reunidas para um poema aberto a

ULYSSES BOSCOLO DE PAULA 
Universidade de São Paulo

Escola de Comunicações e Artes

Ulysses Boscolo de Paula

\section{OS OLHOS DA MONTANHA ENCONTRAM O SOL}

Ilustrações reunidas para um poema aberto ao tempo

Projeto artístico equivalente a Dissertação, apresentado ao Programa de Pós Graduação em Artes, Área de concentração Artes Visuais, linha de pesquisa Poéticas Visuais da Escola de Comunicações e Artes da Universidade de São Paulo, como exigência parcial para a obtenção do Título de Mestre em Artes, sob orientação do Prof. Dr. Luiz Claudio Mubarac.

São Paulo

2012 
Autorizo a reprodução e divulgação total parcial deste trabalho, por qualquer meio convencional ou eletrônico, para fins de estudo e pesquisa, desde que citada a fonte.

ulyssesboscolo1@yahoo.com.br

Catalogação da publicação

Serviço de Documentação

Escola de Comunicações e Artes da Universidade de São Paulo

Paula, Ulysses Boscolo.

Os Olhos da Montanha Encontram o Sol - Ilustrações reunidas para um poema aberto ao tempo; orientador Luiz Claudio Mubarac - São Paulo, 2012.

Dissertação (Mestrado - Programa de Pós Graduação em Artes. Área de Poéticas Visuais). Escola de Comunicações e Artes da Universidade de São Paulo.

1. Gravura 
Nome: Paula, Ulysses Boscolo

Título: Os Olhos da Montanha Encontram o Sol - Ilustrações reunidas para um poema aberto ao tempo.

Projeto artístico equivalente a Dissertação apresentado à Escola de Artes da Universidade de São Paulo para a obtenção do título de Mestre em Artes.

Banca Examinadora:

Prof. Dr. Luiz Claudio Mubarac

Aprovado em São Paulo, de de 2012. 


\section{AGRADECIMENTOS}

Ao professor Claudio Mubarac pela liberdade e confiança no andamento do trabalho, além da presença vital de suas palavras no silêncio do meu ateliê.

A minha esposa Ester Mendes pelo amor.

A Ernesto Bonato pela magia.

Ao Atelier Piratininga que cutucou o poeta sonolento que existe no meu coração. Espero que ele não durma por um longo tempo.

A Samuel Ornelas, Rafael Kenji, Pedro Pessoa, Eduardo Ver, Bruno Oliveira e Marina Faria pela amizade, apesar das minhas falhas.

A Deus pela luz e pelas sombras.

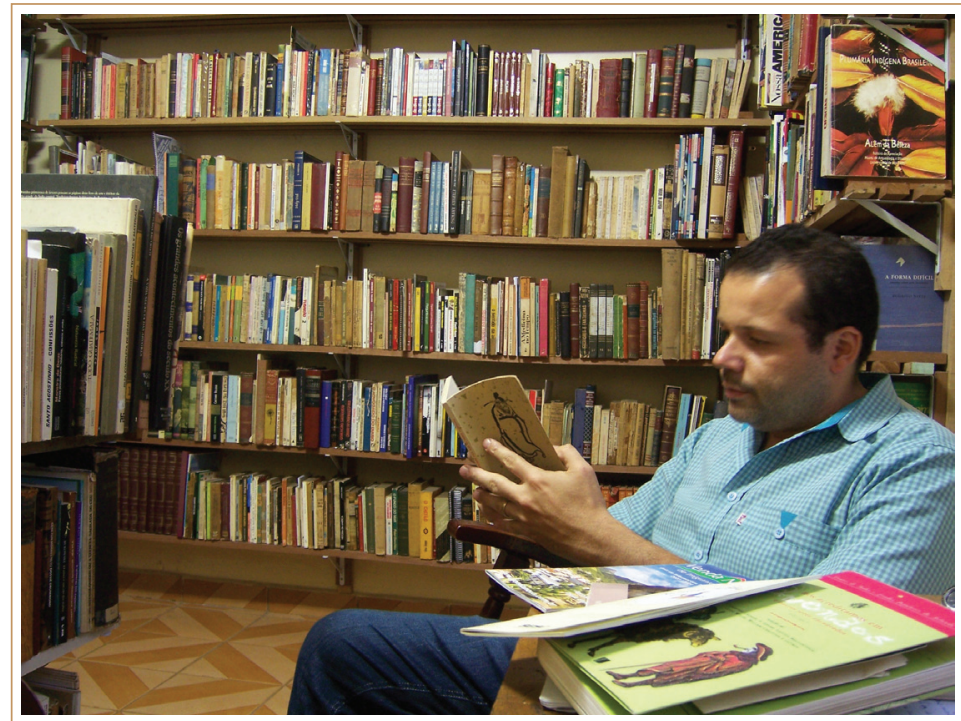


RESUMO

Os Olhos da Montanha Encontram o Sol - ilustrações para um poema aberto ao tempo é o resultado da pesquisa de mestrado que tem por objeto a minha produção artística, na forma de um pequeno portfólio no espelho da xilogravura, entre o verão de 2010 e o inverno de 2012.

O desenho desta pasta é uma reunião (sem ordem aparente) de imagens gravadas na madeira, irrigadas por inúmeras raízes e referências que se desenvolveram dentro e fora da Universidade de São Paulo, a partir de um pequeno poema que criei como lastro.

Coloco na natureza das estampas o meu processo de trabalho, carregando no lombo das ilustrações a ponte entre a palavra e a imagem.

O poema encontra-se incompleto.

\section{Palavras Chave:}

Gravura / Xilogravura 
SUMÁRIO

Os Olhos da Montanha Encontram o Sol.

Sinta-se a vontade para manusear e ler as imagens impressas. Encontre o poema no meio delas. Não há ordem de valores. 